\title{
ABD-Çin Mücadelesi Üzerine Bir Çözümleyici Bağlam Analizi Örneği: Hindistan Stratejik Bir Araç Olabilir Mi?
}

\author{
An Example of Net Assesment on US-China Struggle: Could India Be A Strategic \\ Tool?
}

\author{
Hurşit DINGIIL ${ }^{\text {ID } 1}$, Aydın GÜVEN ${ }^{\text {Di } 2}$
}

\begin{abstract}
$\ddot{O} \mathbf{z}$
Bu makale, ABD’nin Çin’e yönelik stratejilerini Çözümleyici Bağlam Analizi yöntemi çerçevesinde incelemektedir. Özellikle ABD'nin Çin'e karşı uygulayacağ 1 politikalarda Hindistan stratejik bir aktör olabilir mi?' sorusunu Çözümleyici Bağlam Analizi (Net Assessment) temelinde cevaplandırmaya çalışmıştır. Makalede, öncelikle Net Assesment analiz yönteminin çerçevesi çizilerek Türkçe literatüre uygulanmaya çalışı1mıştır. Başvurulan analiz yönteminin oldukça kapsamlı bir yöntem olduğu gerçeği dikkate alınarak söz konusu yöntem dâhilinde çalışmanın konusuna uygun olan unsurlardan yararlanılmıştır. Bu kapsamda, ABD'nin Çin'e yönelik olası hamlelerinin değerlendirilmesi ve tartışılması Çözümleyici Bağlam Analiz yöntemi üzerinden ele alınarak sağlam sonuçlar elde edilmesi hedeflenmiştir. Söz konusu hamlelerin ortaya çıkaracağı muhtemel sonuçlar değerlendirilerek bu hamlelerin Soğuk Savaş dönemi stratejilerinden neden ve nasıl farklılaştıkları nedenleriyle birlikte belirtilmiştir. Devamında ABD'nin küresel liderlik unvanını paylaşmaktan kaçındığı Çin'i sınırlandırmaya yönelik dış politika hamleleri odağında Asya'da önemli bir güç olan Hindistan'ın bu politikalarda uygun bir seçenek olup olmadığ 1 analiz edilmiştir. Hindistan'ın, ABD ve Çin ile olan ilişkileri dikkate alınarak Hindistan örneğinin, ABD'nin bölgedeki geleneksel müttefiklerinden hangi açılardan farklılık gösterdiği belirtilmiş olup bu bağlamda ABD'nin Hindistan üzerinden ne tür bir çevreleme stratejisi geliştirmeye çalıştığı örnekleriyle birlikte açıklanmaya çalışılmıştır. Bu kapsamda ABD'nin Çin'e karşı geliştirdiği stratejiler ve bu stratejilerin muhtemel sonuçları değerlendirilerek söz konusu politikalar çerçevesinde ABD'nin baskın stratejisi tespit edilmeye çalışılmıştır.
\end{abstract}

Anahtar Kelimeler: Çözümleyici bağlam analizi, ABD dış politika analizi, ABD-Çin-Hindistan ilişkileri, küresel güç dengesi, Asya-Pasifik

Makale Türü: Araştırma

\begin{abstract}
This article examines U.S. strategies for China within the framework of NetAssessment Method. The question that "Could India be a strategic tool in the U.S' policies against China?" is answered on the basis of the Net Assessment. In the article, first, the Net Assessment analysis method is framed and tried to be applied to Turkish literature. Considering the fact that the referenced analysis method is a fairly comprehensive method, elements appropriate to the subject of the study are used within the mentioned method. In this context, it is aimed to evaluate and discuss the possible U.S. moves towards China and to achieve solid results through this method. The possible results of these moves are evaluated together with the reasons why and how these moves differ from the Cold War-era strategies. It further analyzed whether India, an important power in Asia in the focus of foreign policy moves to limit China, which the United States refrains from sharing the title of global leadership, was a viable option in these policies. Considering the example of the United States and China in their relations with India, the US and its traditional allies in the region have been noted to various angles in this context, the US is trying to develop what kind of strategy
\end{abstract}

\footnotetext{
${ }^{1}$ İstanbul Medeniyet Üniversitesi, Lisansüstü Eğitim Enstitüsü, Doktora Öğrencisi, hursitdingil@gmail.com.

2̇̇stanbul Medeniyet Üniversitesi, Lisansüstü Eğitim Enstitüsü, Yüksek Lisans Öğrencisi, aydinguven72@gmail.com.
}

Atıf için (to cite): Dingil, H. ve Güven A. (2021). ABD-Çin mücadelesi üzerine bir çözümleyici bağlam analizi örneği: Hindistan stratejik bir araç olabilir mi?. Afyon Kocatepe Üniversitesi Sosyal Bilimler Dergisi, 23(1), 290-302. 
on India are discussed along with related examples. In this context, the strategies developed by the United States against China and their possible results were evaluated and the dominant strategy of the United States was determined within the framework of these policies.

Keywords: Net assessment, USA foreign policy analysis, USA-China-India relations, global balance of power, Asia-Pasific

Paper Type: Research

\section{Giriș}

Son yıllarda uluslararası ilişkilerin yeni odağı olan ABD- Çin karşılaşması, aktörlerin dünyayı etkileyecek büyük oyuncular olmasından dolayı oldukça önem arz etmektedir. Yaklaşık yarım asırdır tek küresel hegemon güç olan $\mathrm{ABD}$, çok kutuplu sistem ile birlikte yeni güçlü ülkelerle yüzleşmektedir. Bu kapsamda, bu yüzleşmenin en önemli aktörlerinden birisi Çin olarak değerlendirilmektedir. Çin, son yıllarda hem ekonomik hem de askeri varlığı ile çok kutupluluğun oluşmasına neden olan aktörlerden birisi olmuştur. Özellikle, ekonomik anlamda sahip olduğu kapasite diğer ülkeleri de etkiler hale gelmiştir.

Çin'in sahip olduğu ve her geçen gün geliştirilen bu kapasite, tüm ülkelerin dikkatini çektiği gibi küresel liderlik pozisyonunu paylaşmak istemeyen ABD'nin de dikkatini fazlasıyla çekmektedir. Bu anlamda ABD, olası Çin'in hamlelerini yakından takip etmekte ve bölgede Çin aleyhine politikalar izlemektedir. Ancak Çin'in temel politikası olarak değerlendirilen kazankazan anlayışı ve Çin'in bölgesel ve küresel hedeflerinin aktörler bazında karşıllıklı kazanç ilişkisine dayanması, ABD tarafından alınan önlemlerde genel bir standart sınır belirlenememesine neden olmaktadır. Bununla birlikte, Çin'in bölgesel ve küresel liderlik niyetindeki baskın belirsizlik, ABD’yi bu konuda geliştireceği politikaların kapsamını belirlemekte etkisiz kılmaktadır. Diğer taraftan, tüm bu belirsizlikler ile beraber ABD'nin posthegemonya sürecinde küresel ilişkilerini nasıl yöneteceği ve bu anlamda hegemonya döneminde tesis ettiği ilişkilerini nasıl şekillendireceği soruları da bu belirsizliğin bir parçası olmaktadır. Öyle ki ABD'nin Asya'daki geleneksel müttefiklerinin, tüm bu süreç dâhilinde karar alma davranışlarını güncellemeye meyilli olup ABD'nin bölgede İkinci Dünya Savaşı sonrası tesis ettiği güvenlik garantörü durumunu sorgular hale geldiği görülmektedir.

Özellikle, çalışmanın ele aldığı ülke olan Hindistan, bu şartlar dâhilinde ‘ABD'nin Çin'e karşı politikalarında stratejik bir araç olabilir mi?' sorusu kapsamında ele alınacaktır. ABD'li karar alıcılar nezdinde Çin'e karşı kullanılabilecek olası stratejide Hindistan'ın değerli bir araç olabileceği varsayımı, bu belirsizlik atmosferini netleştirmeye yardımcı olacaktır. Zira hem akademik değerlendirmelerin hem de karar alıcıların görüşleri doğrudan ya da dolaylı olarak bu belirsizlik üzerinden şekillenmektedir. $\mathrm{Bu}$ doğrultuda uluslararası ilişkilerin temel fonksiyonlarından biri olarak değerlendirilen devletlerin davranışlarını anlamlandırma arayışı, bu konu dâhilinde makalenin ana temasını oluşturmaktadır. Yani ABD'nin çok kutuplu dünya sisteminde sahip olduğu davranışların, Çin'e karşı geliştirilebilecek stratejilerde hem zaman hem de çevre faktörü bağlamında değişebileceği varsayımı ile 'olasılık temelli senaryolar' üzerinden en makul davranışın ne olacağı saptanmaya çalışılacaktır.

Bu anlamda çalışma, öncelikle bir stratejik düşünce ve dış politika analizi yöntemi olan Çözümleyici Bağlam Analizi'ni (Net Assesment) ele alacak ve bu yöntemin esaslarının neler olduğunu ve nasıl geliştiğini ABD'nin Çin'e karşı geliştirdiği politikalarda Hindistan'ın pozisyonunu sorgulayarak inceleyecektir. Bununla birlikte, ABD'nin Çin'e karşı olası stratejilerini tahlil etmek adına öncelikle ABD perspektifinden bölgenin bağlamını ve Çin'e karşı oluşturulabilecek stratejinin muhtemel hedeflerini, araçlarını ve yöntemlerini bir dış politika analizi ve stratejik düşünce yöntemi olan Çözümleyici Bağlam Analizi üzerinden değerlendirecektir. Böylelikle bir ABD karar alıcısı gözünden Asya'da Çin'e karşı geliştirilecek 
olası stratejilerin ve senaryoların nasıl ve neler olabileceği konusundaki değerlendirmeler hali hazırda hem akademide hem de devletler nezdinde süre gelen belirsizliğe bir nebze olsun netlik kazandırmayı amaçlamaktadır. Ayrıca, düşünülen olası stratejilerde Hindistan'ın, Çin'i dengelemek adına uygun bir araç olup olmadığı sorgulanarak Hindistan'ın stratejileri ile birlikte karşılaştırmalı bir zemin oluşturulacaktır. Bu bağlamda, özellikle Hint Okyanusunda Çin'in yükselişi ile süre gelen mücadeleye ve Asya'nın genel dengelerine değinilerek ABD'nin olası stratejileri tartışılacaktır. Sonuç olarak, tüm bu değerlendirmeler neticesinde ABD-Çin-Hindistan sarmalında oluşabilecek olası senaryolar üzerinden en yakın stratejinin hangisi olacağına dair varsayımlarda bulunularak ABD'nin Çin'e yönelik muhtemel politikaları tespit edilmeye çalışılacaktır.

\section{Araştırmanın Yöntemi}

Bu çalışmada, öncelikle Net Assesment analiz yönteminin, Çözümleyici Bağlam Analizi adıyla Türkçe literatüre kazandırılması ve Türkçe uluslararası ilişkiler literatürüne yeni bir kavram kazandırılması amaçlanmıştır. Ayrıca bu yöntemin Türkçe literatüre eklenmesi ile dış politika ve güvenlik çalışmalarına alternatif bir analiz yöntemi kazandırılması hedeflenmiştir.

$\mathrm{Bu}$ doğrultuda çalışmada kullanılan "ABD-Çin güç mücadelesinde Hindistan” örneği, Çözümleyici Bağlam Analizinin ilgili unsurları kapsamında incelenmeye çalışılmışıtır Bu yöntem bağlamında çalışmada ele alınan konu, söz konusu analiz yönteminin başlıca unsurları çerçevesinde incelenmiştir.

\section{2. Çözümleyici Bağlam Analizi (Net Assessment) ve ONA (Office of Net Assessment)}

Türkçe literatürde tam bir karşılığa sahip olmayan, İngilizce 'de "Net Assessment" olarak adlandırılan ve Türkçe’ye çevrildiğinde "Net / Safi / Kesin Değerlendirme" ya da "Ağ Değerlendirmesi" olarak çevrilebilen kavram, bu sözcükler ile kullanıldığında tam olarak İngilizce anlamdaki niteliği ve içeriği karşılamakta yetersiz kalmaktadır. İçinde birden çok fonksiyon ve analitik süreci taşıyan "Net Assessment" temel olarak bütüncül analiz ve analitik değerlendirme yöntemi olarak düşünülmektedir. Yani, "Net Assessment" devletlerin diş ve güvenlik politikalarını oluştururken kullandıkları çok kapsamlı ve boyutlu analitik işlemlerin tümünü kapsayan fonksiyonel bir yöntemdir (Elefteriu, 2018).

"Net Assessment" kavramının kullanımına bakıldığında bu kavramın daha çok bir kurum ile temellendiği görülmektedir. İlk kez 1973 yılında ABD Başkanı Richard Nixon tarafından kurulan 'Office of Net Assessment' (ONA) birimi ile somutluk kazanmıştır. Bu ofis ABD Savunma Bakanlığı bünyesinde yer almakta olup, Pentagon'un düşünsel mekanizması olarak da adlandırılabilir. Diğer taraftan, bu ofisin ilk başkanı ve "Net Assessment" yönteminin kurucusu Andrew Marshall olarak bilinmektedir (Krepinevich \& Watts, 2015).

Marshall, ofis dâhilinde ABD'nin güvenlik ve dış politika kararlarının alınmasındaki baskın kişilerden birisi olarak değerlendirilmektedir. Andrew Marshall ofisin kurucu direktörü olarak yaklaşık 42 yıl aynı görevi sürdürmüş, özellikle ABD’nin Soğuk Savaş’a ilişkin stratejilerinin belirlenmesinde kritik rol oynamıştır. Ayrıca Marshall, yaklaşı olarak 8 ayrı başkanlık döneminde ONA'ya direktörlük yapmıştır. Yine, stratejik düşünce-dış politika analizi ve senaryo planlama konularındaki uzmanlıklarıyla ön plana çıkmış olan Marshall, özellikle Çin'in Soğuk Savaş sonrası ABD için yeni bir tehdit olabileceği öngörüsünde bulunmuştur (Krepinevich \& Watts, 2015).

Çeşitli dönemler dâhilinde, ABD Savunma bakanlarına uluslararası ve bölgesel gelişmelere dair raporlar hazırlayan ONA, ABD Savunma bakanlığının iç 'think-tank'i olarak da bilinmektedir. Soğuk Savaş dönemi ABD’nin diğer önemli dış politika ve güvenlik kurumları topluluğundan gelen sınıflandırılmış bilgilerin tümünü değerlendirme süzgeçlerinden geçirerek oluşturdukları stratejiler ile ABD'nin dış politika ve güvenlik politikalarına yön veren, ABD'nin ulusal çıkar hesaplamalarını yapan ve üst düzey güvenlik seviyesinde korunan bir ofistir (Krepinevich \& Watts, 2015). Özellikle, bu makalenin konularından biri olarak ele alınmasını en 
büyük motivasyonu ABD’nin ulusal güvenlik stratejilerinin oluşturulması sürecinde bu yöntemin kullanılabileceği varsayımı olup eğer ABD nezdinde Çin'e karşı bir strateji belirlenecek olursa bu nasıl belirlenebilir sorusunun cevaplanabileceği temel adres olarak değerlendirilmektedir. Yani ONA'nın kullandığı bu analiz yöntemini anlama uğraşı, ABD’nin Çin'e ilişkin muhtemel stratejilerini anlamlandırma konusunda kolaylık sağlayabilecektir.

"Net Assessment'ın" nasıl bir yöntem olduğunu inceleyecek olursak, bu yöntemin devletlerin özellikle askeri-güvenlik konularında geleceğe dair olası tehditleri belirlemek ve kendi lehine muhtemel avantajları keşfedebilmek için kullandıkları rasyonel bir yöntem olarak da değerlendirilebildiği görülmektedir. "Net Assessment", devletlere olası senaryolar dâhilinde karşılaşacakları zorlukları önceden hesaplayıp değerli manevra kabiliyeti kazandıran stratejik düşünce temelinde kullanılan bir yöntemdir (Elefteriu, 2018). Bununla birlikte, söz konusu yöntemin kendine özgü temel unsurları bulunmakta ve Tablo 1'deki şekliyle sınıflandırılmaktadır

Tablo 1. Çözümleyici bağlam analizi (net assessment) temel unsurları

\begin{tabular}{l}
\hline Asimetrik Kapasitelerin ve Dengelerin Tespit Edilmesi \\
Trendlerin Tespit Edilmesi ve Değerlendirilmesi \\
Uzun Vadeli Kapsamlı Planların Oluşturulması \\
Mevcut ve Gelecekteki Olası Durumlar Üzerinden Karşılaştırmalı Senaryolar Oluşturulması \\
Kritik Rekabet Alanlarında Kıyaslamalı Analizler Yapılması \\
Olasılıklar ve Empati dâhilinde Karar Alma Süreç Analizleri \\
Rekabetçi Doğa Odağıyla Rakibin Olası Bilançosunun ve Dengelerinin Ölçülmesi \\
SWOT+PEST Analizleri \\
Farklılıkların ve Bağlantıların/lilişkilerin Anlamlandırılması \\
\hline
\end{tabular}

Kaynak: (Carnegie Endowment for International Peace, 2017).

$\mathrm{Bu}$ anlamda, "Net Assessment", çok boyutlu ve karmaşık dış politika ve güvenlik sorularının cevaplandırılması noktasında oldukça stratejik ve fonksiyonel bir araç olarak değerlendirilmektedir. Ayrıca, "Net Assessment'ın" en bilenen fonksiyonlarından birisi de karar alıciya en doğru seçenekleri sunma uğraşı olarak değerlendirilmesidir (Konecny, 1988). Dolayısıyla "Net Assessment" gibi böylesine kritik değere sahip analiz yönteminin Türkiye'de dış politika analizi ve güvenlik çalışmaları literatüründe Türkçe anlamda bir karşıllı̆ı olmaması büyük bir boşluk olarak görülmektedir. Bu yüzden, bu makalenin önemli kaygılarından biri de, "Net Assessment" kavramına Türkçe bir karşılık bulma arayışı ve bu yöntemin Türkiye'deki dış politika analizi ve güvenlik çalışmaları literatürüne kazandırılmasıdır.

Öncelikle, tüm bu değerlendirmeler 1şığında Net Assessment'ın niteliğine uygun olduğu düşünülen 'Çözümleyici Bağlam Analizi' kavramı, bu anlamda bir Türkçe karşılık olarak önerilmiştir. Net Assessment'ı genel olarak incelediğimizde görünen iki anahtar kavram bu önerinin geliştirilmesinde önemli bir yer tutmuştur. Birinci kavram "analytic" kelimesi, Latince'de "çözümlemek/çözümleyici" anlamına gelmektedir. Bu anlamda "Net Assesment'da" görülen en büyük özellik ve baskın uğraşı alanı belirlenecek olursa, soruları çözmek ve sorunlara çözümler üretmenin bu yöntemin birincil işlevi olacağı düşünülmektedir. İkinci kavram ise, bağlam kelimesi Türkçe bir kavram olup, olayların meydana geldiği tüm dinamikleri, faktörleri ve atmosferi çok taraflı olarak içine dâhil eden bir anlama sahiptir. Bu iki kavramla "Net Assessment'ın" esas odağı ön plana çıkartılmış ve düşünsel anlamda fonksiyonel bir zemin oluşturulmuştur. Nihayetinde ortaya çıkan yeni Türkçe kavram olan Çözümleyici Bağlam Analizi'nin hem etimolojik hem de düşünsel anlamda istenilen işlevleri çağrıştıracağ 1 düşünülmektedir. Bununla birlikte, bu kavram ifade edildiğinde zihinde istenilen bağdaşma ve ilişkilendirme sürecinin gerçekleşmesine de imkân sağlayabilmektedir. 


\section{ABD’nin Çin'e Karşı Muhtemel Stratejileri: Bir Çözümleyici Bağlam Analizi Örneği}

Son y1llarda yükselen bir güç olarak dünya gündemini oldukça meşgul eden Çin, ekonomi ve teknolojide küresel hegemonyayı sarsıcı ilerleyişiyle ABD'nin dikkatini çekmektedir. Bu süreç ile beraber ABD, geleneksel politikalarını güncelleme ve özellikle Asya genelinde Çin yükselişine karşı stratejiler belirleme arayışına girmiștir. Bu arayış ise söz konusu mücadelenin çok kutuplu bir sistem ile çok boyutluluk kazandığ 1 ve sistemdeki rekabetçi aktör sayısının ve niteliğinin de bu ölçüde değişim gösterdiği bir atmosferde gerçekleştirilmektedir. Buna yol açan durum ise ABD'nin yaklaşık yarım asırdır yürüttüğü tek taraflı hegemonyanın sarsılmaya başlanmasıdır (Chiang, 2015). Bu durumun en temel nedeni çok kutupluluğu çağrıştıran Çin'in her açıdan yükselmesi ve bu doğrultuda küresel liderliğin-gücün bölüşümü olarak değerlendirilmektedir.

Sovyetler Birliği'nin çöküşü sonrasında küresel gücün tekeli haline gelen ABD, geçmişten bu yana bazı geleneksel hegemonyacı davranışlarını sürdürse de bu davranışlar küreselleşen ve hızla değişen sistemde karşılıksız kalmaya başlamıştır. Böylesine bir atmosferde yükselen aktörler de firsatlar dâhilinde hegemonun sahip olduğu gücü paylaşmaya ve uluslararası siyasette etkinliklerini arttırmaya başlamışlardır. Bu durum da ABD'nin hegemonyaya sahip olduğu dönemlerdeki davranışlardan vazgeçmesine zorunlu bir zemin hazırlamaktadır (Chiang, 2015). ABD bir taraftan bu dönüşümün travmalarını yaşarken, diğer taraftan bu dönüşümde nası1 konumlanacağına ve tek küresel güç olarak sürdürülebilirliğini nasıl koruyacağına dair hesaplamalara yönelmiştir. Bu hesaplamaları da ABD temel olarak bazı analiz yöntemlerini ve uygulamalarını kullanarak yapmaktadır. Bu analiz yöntemlerinden birisi de Çözümleyici Bağlam Analizi olarak değerlendirilmektedir.

Öncelikle, ABD'nin Çin'e yönelik uygulayabileceği olası strateji seçeneklerine değinilecek olursa, birinci seçeneğin, ABD'nin tıpkı Soğuk Savaş döneminde SSCB'yi çevreleyerek sınırladığı "Çevreleme Politikası" olarak düşünülmektedir. Bu politika, ABD’nin Moskova Büyükelçiliği'nde çalışan George Kennan tarafından geliştirilmiş olup, SSCB'nin etrafındaki ülkeleri ABD'ye yakın eksene ya da aynı eksene getirecek müttefiklik sistemlerine dâhil ederek, SSCB'yi politik, askeri ve ekonomik anlamda sınırlandırmayı ön görmüştür. Ancak analistler, iki kutuplu Soğuk Savaş atmosferinde SSCB'ye karşı kısmi başarı elde eden bu politikanın Çin'e karşı uygulanamayacağını düşünmektedirler. Çünkü ABD’nin Soğuk Savaş döneminde SSCB ile ilişkilerinin günümüzde Çin ile olan ilişkilerden farklı olduğu bilinmektedir. Kapitalizm ve Sosyalizm çerçevesinde şekillenen Soğuk Savaş atmosferi, yumuşak güç ve ekonomik faktörlerin ön planda olduğu günümüz sisteminden farkl1lık arz etmektedir (Nye, 2018). Dolayısıyla bu görüş, böylesine bir stratejinin karşılıklı bağımlılık ilişkisi bulunan Çin'e karşı uygulanamayacağını açıklayan nedenlerden birisi olarak ileri sürülmektedir (Tellis, 2013).

Bu stratejinin günümüzde Çin'e karşı uygulanamayacağının diğer bir nedeni ise Çin ile ABD'nin ilişkilerinin SSCB ile olduğundan daha farklı bir zeminde ve bağlllıkta olduğu görüşü olup (Nye, 2018) böylesine sinırlayıcı ve keskin bir hamlenin ABD'nin aleyhine sonuçlanabileceği varsayımıdır. Nitekim kutupların sahip olduğu askeri güç ve yönetim açısından benimsediği rejim türünün temel belirleyen olduğu ve dolayısıyla alternatif çıkış yollarının kısıtlı olduğu Soğuk Savaş döneminden ekonomik ve teknolojik gücün yumuşak güç aracılığıyla öne çıktığı, alternatif ittifak değişkenlerinin bulunduğu ve çok kutupluluğun konuşulduğu (Tønnesson, 2015) iç-içe bir dünyaya geçiş yapıldığı bilinen gerçeklerdendir (Rudolf, 2020). Bu anlamda, ABD ile Çin arasında özellikle ekonomik ve teknolojik bağların oldukça iç içe olması (Lu \& Xia, 2010), analistleri olası bir sınırlandırmanın ya da çevrelemenin ABD'yi zora sokabileceği ön kabulüne sevk etmiştir. Analistler temel olarak, Soğuk Savaş döneminde belirleyici olan dinamiklerin ve atmosferin genel itibariyle o dönemin doğasını şu anki uluslararası sistemden her yönüyle farklı olarak değerlendirmektedirler. Bu değerlendirmeler de ABD'nin Çin'e karşı olası "çevreleme-sınırlandırma" politikasını uygulayamayacağı yönündeki baskın motivasyonları göstermektedir. 
ABD'nin ikinci seçeneği ise, çevreleme olmaksızın dengeleme stratejisidir (balancing without containment). Bu strateji, Obama döneminde ilan edilen Pivot ülkeler yani bölgedeki mihver ülkeler ve geleneksel müttefikler üzerinden ABD'nin bölgeye ilişkin politikalarının sürdürülmesini sağlayacak özellikle Çin'i hedefe alan stratejilerden birisidir. $\mathrm{Bu}$ stratejiyi incelediğimizde, genel olarak bölgesel aktörler yoluyla Çin'i dengelemeyi ele alan hedefler bütünü olarak değerlendirilmektedir. Söz konusu seçenekler 1şı̆̆gnda ABD’nin bu dengelemeyi nasıl gerçekleştireceği sorusuna odaklanılacak olursa, temelde Çin'in bölgesel aktörler üzerinden baskılanma politikasının, bu stratejinin esas hedefi olarak ön plana çıktığı görülecektir (Tellis, 2013). Ancak bu politikada caydırıcı olan bazı olasılıklar da bulunmaktadır. Bu anlamda söz konusu olasılıkların başında ekonomik gücün geldiği görülmektedir. Dolayısıyla bu olasılık aynı zamanda bölgesel aktörlerin kendine özgü politikaları ve stratejilerinin ABD'nin bölgedeki çıkarları ile uyuşup uyuşmayacağı endişesini de barındırmaktadır (Chiang, 2015).

Yine, bu endişe ile temellenen bir diğer boyut ise bölgedeki tüm aktörlerin ABD'nin Çin'e karşı muhtemel stratejilerine uygunluk sağlayıp sağlamayacağı sorusudur. Bölgedeki aktörlerin, küresel güç olma yolunda her alanda ilerleme kaydeden ve coğrafi anlamda kendilerine oldukça yakın olan bir güçle olumsuz anlamda yüzleşmesi senaryosu söz konusu soruyu ön plana çıkarmaktadır. Bununla birlikte, ABD'nin bu türden bir stratejisine uyum gösterebilen ülkelerin sayısını düşürebileceği düşüncesi de bu stratejinin karşılaşacağı zorluklardan birisi olarak değerlendirilmektedir.

Ayrıca, bölgesel aktörlerin askeri dengeleri ve ekonomik kapasiteleri üzerinden bir kıyaslama yapılması durumunda Çin, Şekil 1'de de görüldüğü üzere birçok kritere göre bölgedeki baskın güç olarak değerlendirildiğinden bölgedeki ülkeler nezdinde caydırıcı güç olabilmektedir.

Şekil 1. Asya kıtası ülkelerini askeri dengeler göstergesi

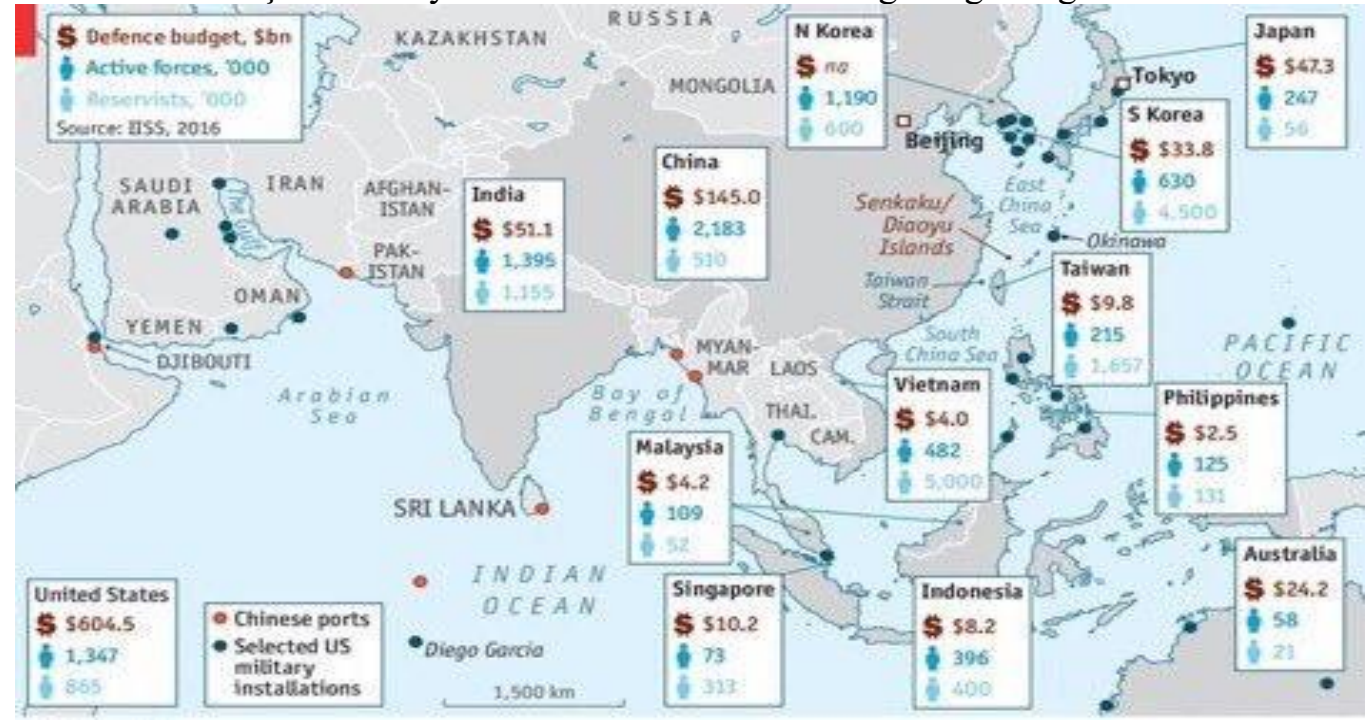

(The Economist, 2020).

$\mathrm{Bu}$ durum bölge ülkelerini her ne kadar güçlü bir aktörle ittifaka meyilli olmaya zorlasa da ittifakın ABD ve Çin arasından olabileceği gerçeği her zaman çok kutuplu sistemin dinamikleri dâhilinde ABD lehinde sonuçlanmayacağı olasılığını ortaya çıkarmaktadır (McDaniel, 2012). Bu düşünceler, bu stratejinin uygulanması durumunda muhtemel dezavantajları da ortaya çıkarmaktadır. Yine bölgesel aktörlerin ekonomik yönelimleri ve arzuları dikkate alındı̆̆ında, bölgede ekonomik olarak baskın komunda olan Çin ile ticari ilişkilerinin iyi bir seyirde olması kendilerine yönelik bir baskı unsuru oluşturmaktadır (Tellis, 2013).

Bölgesel aktörlerin bir diğer endişesi ise İkinci Dünya Savaşı sonrası ASEAN üzerinden sağlanan ABD'nin bölgesel güvenlik garantörlüğünün sürdürülebilir olup olmayacağıdır. Çünkü 
ABD'nin hegemonya sonrası bir sürece girmesi, kendi ülke sınırları içinde maruz kaldığı sorunlar ve dünyanın farklı bölgelerindeki cephelerde tükettiği güç ve enerjiyi yeniden toparlayabilme arayışı, ABD'yi kendi sınırlarına çekilme eğilimine sevk etmiştir. Bu durumun, farkında olan bölgesel aktörler, ABD ile geleneksel ilişkilerini gözden geçirme arayışına girerek kendilerine özgü ulusal menfaatleri önceleyen politikalara meyilli hale gelmektedirler. Özellikle, Çin'in bölgesel ve küresel hedeflerinde baskın olan belirsizlik, bölgesel aktörleri bu anlamda endişelendiren bir trende dönüşmüştür. Bölgede süre gelen bu trend, ABD'li analistler için senaryo dâhilinde karşılaş1labilecek bir zorluk olarak değerlendirilmektedir. Tüm bu değerlendirmeler, Çin'in sınırlandırılma olmadan dengelenmesi stratejisi seçeneğinde temel dezavantajlar olarak değerlendirilmektedir. Bundan dolayı bu stratejinin de uygulanabilir olup olmayacağı analistlerin temel endişesini oluşturmaktadır (Biswas \& Goel, 2018).

Üçüncü seçenek olarak ise Çitleme (Hedging) stratejisi ileri sürülmektedir. Bu kapsamda, öncelikle Hedging kavramı incelendiğinde Hedging kelimesinin finansal bir kavram olup, ekonomik varlıkları korumak amacıyla iki tezat politikanın aynı anda yürütülmesi anlamında kullanıldığı görülmektedir (Hemmings, 2013). Bundan dolayı Hedging kelimesine rasyonel bir Türkçe karş1lı düşünüldüğünde, "Güdümlü Dengecilik" kavramının uygun olduğu görülmektedir. Bu doğrultuda, ABD’nin Çin'e ilişkin belirlediği hedeflerin doğal olarak kullanılan araçları hedefe güdümlü kıldığı düşünülmektedir. Bu durum da bu hedef için birbirine tezat olan iki farklı aracın kullanılması anlamına geldiğinden, bu iki araç arasında oluşturulan ve arzu edilen bir denge, araçları hedefe güdümlü olmaya itmektedir.

Bu bağlamda, ABD, Çin'e karşı oluşturacağı stratejide temel hedefe ulaşmak üzere birbirine tezat iki farklı politikayı temele alan "Güdümlü Dengeciliği" (Hedging) kullanabilecektir. Bu tezat politikalardan birisi Çin ile bağımlılı̆̆ arttırmayı hedeflerken, diğeri ise Çin'e karşı caydırıcılık oluşturmayı amaçlamaktadır. Bu anlamda, söz konusu tezat politikalar, tek hedef olan Çin'e karşı caydırıcılık oluşturmaya yöneliktir. Böylelikle bölgesel/geleneksel müttefikler üzerinden Çin'e karşı caydırıcılık oluşturulacak ve ABD’nin bölgedeki askeri varlığı sürdürülebilir kılınarak bu caydırıcılık temellendirilebilecektir (Tellis, 2013). Diğer taraftan ise Çin'in liberal ekonomik sisteme bağlılığı ve angaje durumu arttırılarak, sistem içinde Çin; sistemin kurallarına fazlasıyla bağlı, sistem ile uyumlu bir aktör haline getirilmeye çalışılacaktır (RAND Corporation, 2014). Bunun en büyük ayağı ise liberal ekonomik sistemin bir sonucu olan uluslararası kuruluşların etkinliğinin arttırılması ile Çin'in durdurulabileceği varsayımıdır. Nitekim günümüzde sürekli olarak Çin'i, evrensel insan haklarına aykırı hareket etmesi ve dünya barışı ve düzenine zarar verdiği söylemleri üzerinden suçlayan ABD yönetiminin, Çin'i liberal dünyanın kuralları çerçevesinde sınırlandırması düşüncesi bu stratejinin önemli bir ayağını oluşturmaktadır.

Dördüncü muhtemel seçenek ise çevreleme stratejisini uygulayabilecek bir ortam oluşturma girişimi olarak düşünülmektedir. Bu stratejiyle mevcut koşullarda Çin'e karşı bir çevreleme uygulanamayacağ 1 gerçeği dikkate alınarak, çevreleme stratejisinin uygulanmasını sağlayacak Soğuk Savaş dinamiklerini oluşturmak üzere bir yöntem kullanılması öncelenmektedir. Bu stratejiye Ayrışma (Decoupling) denilmektedir (Pethokoukis, 2020). Bu stratejinin temel hedefi çevreleme stratejisini uygulayabilecek bir ortam oluşturmak üzerinden şekillenmekte olup bu hedefe ulaşmanın makul yolunun Çin-ABD ilişkilerinde ekonomi başta olmak üzere başlatılacak ayrışma yöntemine başvurmak olduğu ileri sürülmüştür. Bu hususta Sovyetler ile ABD arasındaki koşullara benzer bir durum oluşturulup çevreleme stratejisi için elverişli bir ortam hazırlanacaktır. Esasında çevreleme için uygun olmayan ABD-Çin ilişkilerinin mevcut durumunu Soğuk Savaş döneminde ABD-SSCB ilişkilerine benzer hale getirmek amaçlanmaktadır (Logan, 2020).

Tüm bu değerlendirmeler 1şı̆̆ında, bir stratejinin olmazsa olmaz unsurları üzerinden çalışmayı ele alacak olursak, ABD'nin, geliştirdiği bir takım temel strateji ile Çin'in Soğuk Savaş sonrası sistemde ABD'nin tek başına sahip olduğu süper güç unvanını düşürmesi veya onu paylaşması girişimlerinin önünü almaya çalıştığı görülmektedir. Bu bağlamda bu stratejilerin 
temelinde sıcak bir savaş ve çatışmaya girilmeksizin ABD'nin bölgede Çin ile dengelisürdürülebilir bir ilişki tesis edilmesi ABD’nin olası ve baskın hedefi olarak yer almaktadır. Bununla birlikte, bu hedefe ilişkin araçlar da yukarıda incelenen politikalar olduğundan yöntem ise genel anlamda baskın gelen " güdümlü dengeleme" olarak düşünülmektedir.

Böyle olası bir değerlendirmede belirlenen stratejinin uygulanacağı bölgeye bakıldığında söz konusu bölgenin Asya kıtası olduğu görülmektedir. Bir taraftan Asya bölgesinin baskın faktörü olarak çok kutuplu sistem dâhilinde dönüşüm içinde olan bölgesel dengeler diğer taraftan ise tüm bu dinamikleri kuşatan temel baskın değer olarak aşırı seviyede karşı karşıya kalınan belirsizlik durumu bölgeye ilişkin temel bir görünüm olarak değerlendirilebilir. Öyle ki bu belirsizlik hem bölgesel dengelere hem de dengelerin oluşmasının temel kaynağı olan bölgesel aktörlere etki etmektedir. Dolayısıyla bu belirsizlik durumu, bölgede gelişebilecek muhtemel siyasete dair bir takım endişe teşkil etmektedir.

Tüm senaryolar ve Çözümleyici Bağlam Analizi 1şı̆̆ında ABD'nin bölgede Çin yükselişini engellemeye yönelik stratejileri, bölge ülkelerinin iki büyük güç arasındaki tutumu ve Çin'in bunlara karşı geliştireceği politikalar dâhilinde bazı sonuçlara varılmıştır. Birincisi Çin'in geliştirilen stratejiler ve alınan önlemler karşısında sistemin kurallarına uyan bir aktör olması durumudur. Bu durum ABD'nin istediği bir sonuç olup gerçekleşmesi halinde ABD'nin başarılı olduğunun temel belirtisi olacaktır. İkincisi, Çin'in yükselişini sürdürüp mevcut sistemi temelli değiştirerek kendi lehinde sonuçlar üretmesi durumudur. Böyle bir sonuç ABD'nin küresel süper güç konumundaki rolünü değiştireceği gibi yeni süper güçleri kabullenmesini de beraberinde getirecektir. Üçüncü durum ise son zamanlarda alevlenen ticaret savaşları sonucunda Çin'in geliştireceği stratejilerle mevcut liberal ekonomik sistemi temelli yıkacağı olasılığıdır. Bu üç muhtemel seçenek tüm olası senaryoların sonuçları olarak düşünülmektedir (RAND Corporation, 2014).

Söz konusu olasılıklar, ABD’nin Soğuk Savaşın sona ermesinden beri müttefikleri üzerinden yürüttüğü geleneksel stratejilerinin Çin'i sınırlandırma için yetersiz kaldığı görülmektedir. Dolayısıyla Çin'in ekonomik ve askeri yönden yükselmesi ve dünya genelinde nüfuz ve manevra alanını genişletmeye devam etmesi ABD'yi endişelendirmekle kalmamış aynı zamanda doğrudan strateji geliştirip Çin'in yayılmasına engel olacak politikalar geliştirmesine yol açmıştır. Bu bağlamda Asya bölgesinde 'aktif hâkimiyet politikası' yürüterek Çin'i sınırlandırmaya çalışan ABD'nin söz konusu politikayı bölgedeki müttefikleri üzerinden yürütmeye çalıştığ1 görülmektedir. Başta Japonya olmak üzere bölgedeki müttefikleri üzerinden yürüttüğü stratejilerin yetersizliğinin farkına varan ABD'nin, Hindistan gibi gelişmekte olan ve bölgede Çin'e rakip olma potansiyeli barındıran bir ülke ile işbirliği geliştirmesi hem Hindistan'ın sahip olduğu potansiyeli hem de $\mathrm{ABD}$ açısından üstleneceği rolün ne olacağı gibi soruları beraberinde getirmiştir. Bu bağlamda çalışmanın temel sorularından birisi olarak Hindistan ABD'nin bu muhtemel stratejilerinde kullanışlı bir araç olabilir mi sorusunun cevaplandırılması çalışmanın amacına ulaşması adına önem arz etmektedir.

\section{Hindistan ABD İçin Stratejik Bir Araç Olabilir mi?}

$\mathrm{Bu}$ makalenin temel sorularından birisi olması hasebiyle "Hindistan, ABD'nin Çin'i Asya'da sınırlandırmaya yönelik muhtemel stratejilerinde sonuç odaklı ve kullanışlı bir araç olabilir mi" sorusunu cevaplandırmak için öncelikle Hindistan-ABD ilişkilerine genel olarak değinmek gerekmektedir. Bu bağlamda ABD'nin Asya'daki hedeflerinin bir parçası olarak Hindistan ile stratejik ilişkiler geliştirmesi Çözümleyici Bağlam Analizi yönteminin temel unsurlarını karşılayan bir örnektir. Çözümleyici Bağlam Analizi'nin başvurduğu başlıca unsurlardan rekabet ortamı, uzun vadeli kapsamlı planların oluşturulması, asimetrik kapasitelerin ve dengelerin tespit edilmesine ilişkin senaryolar, Hindistan'ın, ABD ve Çin arasındaki güç mücadelesinde nasıl bir role sahip olduğunu açıklar niteliktedir. Söz konusu unsurların temellendirilmesi için Hindistan$\mathrm{ABD}$ arasındaki ilişkilerin çerçevesinin belirlenmesi uygun olacaktır. 
Hindistan- ABD ilişkilerinin Soğuk Savaş sonrası her açıdan gelişen bir çizgide olduğu görülmektedir (Pant, 2019). Soğuk Savaş döneminde Hindistan, Bağlantısızlık Hareketi'ne öncülük yapıp hiçbir kutupta yer almamasına rağmen ABD'nin Pakistan yanlısı bir politika izlemesi sonucu Doğu Bloku'na yanaşmıştır. Özellikle askeri alanda SSCB ile yakın işbirliği içinde olan Hindistan, SSCB'nin dağılması üzerine başlattığı çok boyutlu dış politika kapsamında ABD ile her alanda işbirliği geliştirmeye çalışmıştır. Hindistan'ın bu girişimi ve onun sahip olduğu potansiyelin farkında olan $\mathrm{ABD}$, Soğuk Savaş sonrası dönemde Hindistan- ABD ilişkilerinin her alanda gelişmesi yönünde çaba harcamıştır. (Bajpai, 2010).

ABD ile geç başlayan ilişkiler, Hindistan'ın nükleer silah sahibi olması ile birlikte tekrar gerilmesine rağmen Hindistan'ın bölgesel anlamda önemli bir müttefik olacağının farkına varan ABD, Nükleer Silahların Yayılmasının Önlenmesi Antlaşması konusunda Hindistan'a imtiyaz vermiştir. $\mathrm{Bu}$ durum da $\mathrm{ABD}$-Hindistan ilişkilerinin seyrinin iyi yönde ilerlemesine olanak sağlamıştır. Bu dönemden sonra özellikle Hindistan ile savunma ve güvenlik konularında işbirliği geliştiren ABD, Asya Pivot stratejisi yoluyla Hindistan ile ilişkilerini stratejik seviyeye getirmiştir (Council on Foreign Relations(cfr), 2020).

$\mathrm{Bu}$ anlamda ABD - Hindistan ilişkileri, ABD'nin Çin'e karşı belirleyeceği muhtemel stratejilerde Hindistan'ın bir araç olarak kullanılmasına yönelik iyi bir zemin sunmaktadır. Hindistan'ın hedefleri bağlamında bir inceleme yapıldığında Hindistan'ın Soğuk Savaş sonrası Doğuya Bakış (Look East) politikasını benimsediği ve özellikle bu politika yoluyla başta Güneydoğu Asya ülkeleri olmak üzere komşu ülkelerle iyi ekonomik ve siyasal ilişkiler geliştirmeyi hedeflediği görülmektedir (Haokip, 2011). Ayrıca Önce Komşuluk (Neighbourhood First) politikası ile komşularıyla yakın işbirliği geliştirerek onların Çin eksenine girmesine mani olmaya çalışmaktadır. Bu politika, ABD'nin değinilen hedef ve stratejilerine uygun olup bir bakıma Çin etki alanının kısıtlanması amacını taşımaktadır.

Bununla birlikte, Hindistan, ticaretinin \%90'nının bağlı olduğu Hint Okyanusu'na hem dış politikasında hem de ekonomi politikalarında birincil önem atfetmektedir (Kaplan, 2009). Bu bağlamda Hindistan, Hint Okyanusu'nun korunmas1, Hint Okyanusu'ndaki korsanlık faaliyetleri ile mücadeleyi, bölgedeki etkinliğini sağlamasını temele alan "Sea Lines of Communications" (SLOC) stratejisini benimsemektedir (Nagao, 2020). Hindistan bu strateji çerçevesinde belirlediği deniz iletişim hatlarını korumayı bu stratejinin temel hedefi olarak değerlendirmektedir (Scott, 2008).

$\mathrm{Bu}$ anlamda, Hindistan özellikle Güney Çin Denizi’nde süre gelen sorunlardan ve anlaşmazlıklardan bilhassa son yıllarda yükselişiyle baskın hale gelen Çin'den endişe duymaktadır. Çünkü Güney Çin Denizi'nde etkin olan Çin, ardından Hint Okyanusu'nda da etkin olmak isteyebilecektir düşüncesi bu endişenin temel kaynağını oluşturmaktadır. Diğer taraftan, Çin'in Hint Okyanusu'nu da içine alan "String of Pearls (İnci Dizisi)" stratejisi bu endişeyi haklı kılar niteliktedir. Zira bu strateji Çin'in "Kuşak-Yol Projesi'nin” denizleri kapsayan kısmını oluşturmaktadır (McDaniel, 2012). Çin bu strateji ile ortağ1 ya da sahibi-işletmecisi olduğu limanlar üzerinden küresel deniz ağını kurmaya çalışmaktadır. Ayrıca, Hindistan ile Çin arasındaki diğer problemlere de bakacak olursak, Hindistan ve Çin arasında geçmişten gelen sınır sorunları iki ülke arasında problemli bir ilişkiye sebep olmaktadır. Bu anlamda, Çin ile Hindistan arasında süre gelen Keşmir problemi, Tibet sorunu ve diğer sınır paylaşım sorunları, ilişkilerin sürekli gergin olmasına neden olmaktadır (McDaniel, 2012). Özellikle son dönemlerde taraflar arasında meydana gelen sınır çatışmaları da göz önüne alındığında Hindistan'ın Çin'e karşı mesafeli duruşu daha da keskinleşmektedir.

Bu değerlendirmeler 1şığında, "Hindistan, ABD'nin Çin'e karşı stratejilerinde değerli bir araç olabilir mi ?" sorusunu cevaplayacak olursak, Çözümleyici Bağlam Analizi’nin de sunduğu üzere uzun vadeli kapsamlı planların oluşturulması açısından ABD'nin oldukça önemli avantajlara sahip olduğu görülmekte olup Hindistan'ın ABD için değerli bir firsat dizini sunduğu düşünülmektedir. Özellikle Hindistan - Çin arasında süre gelen gergin-olumsuz ilişkiler ABD’nin 
Çin'e karşı Hindistan'ı destekleyip stratejik anlamda Çin'i kısıtlama politikasına uygun bir zemin hazırlamaktadır (Abraham, 2020). Hindistan'ın hem demografik açıdan hem de ekonomik olarak bölgedeki ikinci güçlü devlet olması, ABD'nin muhtemel stratejilerini uygulatacak en uygun partner görünümünü doğurmaktadır. Ayrıca Hindistan'ın ticaretinin ve ticaret yollarının $\% 90$ oranında bağlı olduğu Hint Okyanusu üzerinde Çin'in son yıllarda dillendirilen söylemleri Hindistan'1 endişelendirmekte ve bu yolla Çin'e karşı ABD gibi müttefikler yolu ile önlem almasına yol açmaktadır (Rudolph, 2018). Bu bağlamda Hindistan için bir ulusal güvenlik önceliği olan Hint Okyanusu, Çin'in bölgedeki arzularına karşı ABD ile yapılacak denizlerin güvenliğini koruma ve Hindistan'ın aktivitelerini sürdürmesini sağlayacak işbirlikleri Hindistan nezdinde oldukça önemli bir yere sahip olduğu gibi ABD için de Çin'in bölgede kısıtlanması bağlamında değerli firsatlar sunmaktadır (McDaniel, 2012).

Aynı zamanda ABD ile ilişsilerin bu alanlarda gelişmesi, Hindistan'ın bölgedeki diğer geleneksel ABD müttefikleri ile de siyasal ilişkilerini geliştirmesine yol açmaktadır. Bu durum ise ABD'nin öncelikli politikalarından biri olan Çin'i yükseldiği bölgede sıkıştırmak ve bölgede nüfuz alanını daraltmak politikasına zemin hazırlamaktadır (Güven, 2020). Nitekim 1962 yılında Çin'e karşı kaybettiği savaştan sonra ortaya çıkan güvensizlik algısı (Ogden, 2016) Hindistan'ın son dönemlerde özellikle deniz alanında Japonya ve Avustralya gibi ABD müttefikleri ile ortak tatbikatlar geliştirmesine yol açmış ve bu yolla Çin tehdidine karşı ittifak görüntüsü verilmesi amaçlanmıştır (Babones, 2020).

Çözümleyici Bağlam Analizi unsurlarına başvurularak yapılan analizler doğrultusunda Hindistan-ABD ilişkileri kazan-kazan temelinde şekilleneceğinden, ABD'nin Çin'e karşı geliştireceği strateji senaryolarında Hindistan'ın stratejik bir aktör olabilecek nitelikte olduğu sonucuna varılmıştır. Ancak Hindistan ve Çin arasında komşuluktan ve sahip oldukları tüketici pazarlarından kaynaklanan ticari ilişkilerin iştah verici boyutlarda olması, Yeni Delhi'nin Pekin'i keskin bir şekilde karşısına alamayacağı görüşlerini de ortaya çıkarmaktadır.

\section{Sonuç}

Bu makale, ABD’nin karar alma süreçlerinde kullanılan etkili bir analiz yöntemi olarak değerlendirilen Çözümleyici Bağlam Analizi (Net Assesment) yöntemi temelinde Çin'e karş1 ABD'nin olası stratejilerini incelemiştir. Bu anlamda, Türkçe karşılığ olmayan "Net Assessment" analiz yönteminin, temel unsurlarını anlamlı bir şekilde kapsayan Çözümleyici Bağlam Analizi olarak Türkçe literatüre kazandırılması amaçlanmıştır. Bununla birlikte başvurulan analiz yönteminin oldukça kapsamlı bir yöntem olduğu gerçeği dikkate alınarak söz konusu yöntem dahilinde çalışmanın konusuna uygun olan unsurlardan yararlanılmıştır..

Devamında ABD'nin Çin'e karşı olası strateji senaryoları değerlendirilmiştir. Çok kutuplu uluslararası sistem dâhilinde ABD'nin nasıl bir davranış sergileyeceği konusunda olası çıkarımlar yapılarak ABD'nin Asya'da Çin'e karşı muhtemel stratejilerinin anlaşılması kolaylaştırılmaya çalışılmıştır. Bu bağlamda Çözümleyici Bağlam Analizi ışığında yapılan değerlendirmeler sonucu ABD'nin Çin' karşı geliştirebileceği muhtemel stratejilerin aşağıdaki şekilde olduğu sonucuna varılmıştır:

- Birincisi 'Çevreleme Politikası'dır. Ancak mevcut konjonktürde ABD-Çin arasındaki ilişkilerin Soğuk Savaş dönemi ABD-SSCB ilişkilerinden çok farklı olması nedeniyle bu stratejinin başarılı olması düşünülemez.

- İkincisi 'çevreleme olmaksızın dengeleme' stratejisidir (balancing without containment). Bu strateji çerçevesinde $\mathrm{ABD}$, bölgedeki müttefikleri üzerinden Çin'in bölgedeki faaliyet alanını kısıtlamaya çalışmaktadır. Bu stratejiye geleneksel ABD müttefiklerinin yanı sıra Hindistan da dâhil edilmeye çalışılmaktadır. Bu seçenek belirlenen hedefe ulaşabilecek bir strateji gibi görünse de Çin'in bölgedeki ekonomik caydırıcılığı bölge ülkeleri nezdinde bir baskı ve belirsizlik hissine yol açma potansiyeli barındırmaktadır. Ayrıca bölge ülkelerinin $\mathrm{ABD}$ garantörlüğü konusunda da belirli endişelerinin olduğu söz 
konusudur. Soğuk Savaş döneminde ASEAN üzerinden sağlanan ABD'nin bölgesel güvenlik garantörlügünün sürdürülebilir olup olmayacağı konusundaki tereddütler bölge ülkelerinin Çin'e karşı net bir duruş sergilemesinin önüne geçmektedir.

- Üçüncüsü, Çitleme (Hedging) stratejisidir. "Güdümlü Dengecilik” olarak kullanılan bu stratejide ABD hedeflediği amaca ulaşmak adına birbirine tezat iki politika geliştirdiği sonucuna ulaşılmıştır. Stratejinin nihai amacı Çin'e karş1 oluşturulacak caydırıcılık mekanizması ile Çin'i liberal ekonomik sisteme angaje etmektir. Bu yolla Çin'in dengelenmesi düşünülmektedir. Ancak görüldüğüü üzere Dünya Ticaret Örgütüne üye olduğundan beri Çin, hem liberal sistemin nimetlerinden yararlanmış hem de yönetim tarzı ve geleneksel tutumundan taviz vermemiştir.

- Dördüncü muhtemel seçenek ise geleneksel çevreleme stratejisini uygulayabilecek bir ortam oluşturmaktır. Ayrışma (Decoupling) olarak ele alınan bu stratejide, Soğuk Savaş döneminde ABD ve Sovyetler Birliği ilişkilerinden çok daha farklı ve iç içe olan ABD ve Çin ilişkileri dikkate alınarak özellikle ekonomik koşullar üzerinden bir Soğuk Savaş ortamı oluşturulmak istenmektedir.

Tüm senaryolar ve Çözümleyici Bağlam Analizi ışı̆̆ında ABD’nin Çin yükselişine karşı geliştirmesi muhtemel stratejiler, beraberinde aşağıdaki gibi bazı sonuçlar doğurmaktadır. Söz konusu muhtemel sonuçlardan ilki, Çin'in geliştirilen stratejilere karşı dengelenmesi ve ABD liderliğindeki sistemin kurallarına uyan bir aktör olması durumudur. İkincisi, Çin'in söz konusu stratejilere karşılık vermesi ve yakaladığ 1 ivme ile mevcut sistemi temelli değiştirerek kendi lehinde sonuçlar üretmesi durumudur. Bu durum ABD'nin tek süper güç olma rolünü ortadan kaldıracağ 1 gibi çok kutupluluğu da beraberinde getirecektir. Üçüncü durum ise son dönemlerde gittikçe artan ticaret savaşları sonucunda Çin'in geliştireceği karşı stratejilerle liberal ekonomik sistemi temelli yıkacağı olasılığıdır. Bu üç muhtemel senaryo belirtilen stratejilerin muhtemel sonuçları olarak ortaya çıkmaktadır.

Özellikle bu stratejilerde ve muhtemel sonuçlar 1şığında ABD'nin Çin'e karşı olası stratejilerinde Hindistan'ın değerli bir araç olabileceği birçok anlamda güçlü bir zemin bulmaktadır. Esasen, Hindistan'ın sahip olduğu münhasır şartlar, ABD'nin olası stratejilerinde önemli bir rol oynamaktadır. Diğer taraftan 21. yüzyılla birlikte uluslararası sistemde yaşanan dönüşüm ile beraber ABD tarafından Çin'e karşı pozisyon alması beklenen bölge ülkelerinin tutumlarında belirsizlikler Hindistan'a biçilen rolün değerini artırmaktadır.

\section{Kaynakça}

Abraham, J. C. (2020). Indo-US Convergence in the Indo-Pacific: China's Containment and Lingering Constraints. Journal Of Culture, Politics And Innovation.

Babones, S. (2020). India Doesn't Need the Quad to Counter China-and Neither Do Its Partners. Foreign Policy: https://foreignpolicy.com/2020/10/05/india-quad-alliance-chinacontainment/ (Erişim Tarihi: 25.10.2020)

Bajpai, K. (2010). India and the World. N. G. Jayal içinde, The Oxford Companion to Politics in India (s. 521-541). New Delhi: Oxford University Press.

Biswas, B., \& Goel, A. (2018, 12 19). What Comes After US Hegemony? The Diplomat: https://thediplomat.com/2018/12/what-comes-after-us-hegemony/ (Erişim Tarihi: 27.10.2020)

Carnegie Endowment for International Peace. (2017). China's military \& the US-Japan alliance in 2030: A Strategic net assessment. Carnegie Endowment for International Peace. 
Chiang, M.-H. (2015). The U.S. Hegemony, East Asia, Global Governance. Bandung: Journal of Global South.

Council on Foreign Relations(cfr). (2020, Ocak 07). Council on Foreign Relations "Timeline:UsIndia Relations". Council on Foreign Relations: https://www.cfr.org/timeline/us-indiarelations (Erişim Tarihi: 25.10.2020)

Elefteriu, G. (2018). Towards Better UK Strategy Through Net Assessment. A Question of Power, 13-30.

Güven, A. (2020). Asya-Pasifik Güç Mücadelesinde Hindistan'ın Rolü: ABD-Çin Jeopolitik Güç Sarmall. İlim ve Medeniyet: https://www.ilimvemedeniyet.com/asya-pasifik-gucmucadelesinde-hindistanin-rolu-abd-cin-jeopolitik-guc-sarmali.html (Erişim Tarihi: 20.10.2020)

Haokip, T. (2011). India's Look East Policy: Its Evolution and Approach. South Asian Survey, 239-257.

Hemmings, J. (2013). Hedging: The Real U.S. Policy Towards China? The Diplomat: https://thediplomat.com/2013/05/hedging-the-real-u-s-policy-towards-china/ (Erişim Tarihi: 20.10.2020)

Kaplan, R. D. (2009). Center stage for the twenty-first century: Power Plays in the Indian Ocean. Foreign Affairs, 16-32.

Konecny, D. (1988). Net Assessment: An Examınation of the Process. Naval Postgraduate School.

Krepinevich, A. F., \& Watts, B. (2015). The last warrior Andrew Marshall and the shaping of modern American defense strategy. New York: Basic Books.

Logan, J. (2020). No One Has a Clue What to Do About China. The National Interest: https://nationalinterest.org/feature/no-one-has-clue-what-do-about-china-152781 (Erişim Tarihi: 15.10 .2020$)$

Lu, C., \& Xia, M. (2010). The interdependence between China and the United States: a two-level analysis. Korean Journal of Defense Analysis, 321-339.

McDaniel, C. D. (2012). India, China and the United States in the Indo-Pacific region: coalition, co-existence or clash? Canberra: Australian Defence College.

Nagao, S. (2020). The Growing Militarization of the Indian Ocean Power Game and Its Significance for Japan. SPF: https://www.spf.org/iina/en/articles/nagao-indiapowergame.html (Erişim Tarihi: 25.10.2020)

Nye, J. S. (2018). The Cooperative Rivalry of US-China Relations. Project Syndicate: https://www.project-syndicate.org/commentary/china-america-relationship-cooperativerivalry-by-joseph-s--nye-2018-11?barrier=accesspaylog (Erişim Tarihi: 25.10.2020)

Ogden, C. (2016). Hindistan Dış Politikası. (A. Y. Şir, Çev.) İstanbul: İyidüşün Yayınları.

Pant, H. V. (2019). The India-US-China triangle from New Delhi: overcoming the "hesitations of history". India Review, 18(4), 386-406.

Pethokoukis, J. (2020). Are We Really Trying to Decouple From China? The National Interest: https://nationalinterest.org/blog/buzz/are-we-really-trying-decouple-china-118886 (Erişim Tarihi: 01.11.2020)

Rand Corporation. (2014). Developing a U.S. Strategy For Dealing with China-Now and into the Future. Rand Corporation. 
Rudolf, P. (2020). The Sino-American World Conflict. German Institute for International and Security Affairs.

Rudolph, J. (2018). Checkmating Chinas Growing Influence. alpha Editions.

Scott, D. (2008). The Great Power 'Great Game' between Inidia and China:"The Logic of Geography". Geopolitics.

Tellis, A. J. (2013). Balancing without Containment: A U.S. Strategy for Confronting China's Rise. The Washington Quarterly .

The Economist. (2020). Disorder under heaven: America and China's strategic relationship. The Economist:

https://www.economist.com/taxonomy/term/76972/DatabookDec2014\%20212.pdf?page=96 (Erişim Tarihi: 05.11.2020)

Tønnesson, S. ( 2015). Deterrence, interdependence and Sino-US peace. Vol 18(3), International Area Studies Review, 297-311.

\section{ETIKK ve BİLIMSEL İLKELER SORUMLULUK BEYANI}

$\mathrm{Bu}$ çalışmanın tüm hazırlanma süreçlerinde etik kurallara ve bilimsel atıf gösterme ilkelerine riayet edildiğini yazarlar beyan eder. Aksi bir durumun tespiti halinde Afyon Kocatepe Üniversitesi Sosyal Bilimler Dergisi'nin hiçbir sorumluluğu olmayıp, tüm sorumluluk makale yazarlarına aittir.

\section{ARAŞTIRMACILARIN MAKALEYE KATKI ORANI BEYANI}

1. yazar katk1 oranı: $\% 50$

2. yazar katk1 oranı: $\% 50$ 